\title{
Eschatology in Malachi: The emergence of a doctrine
}

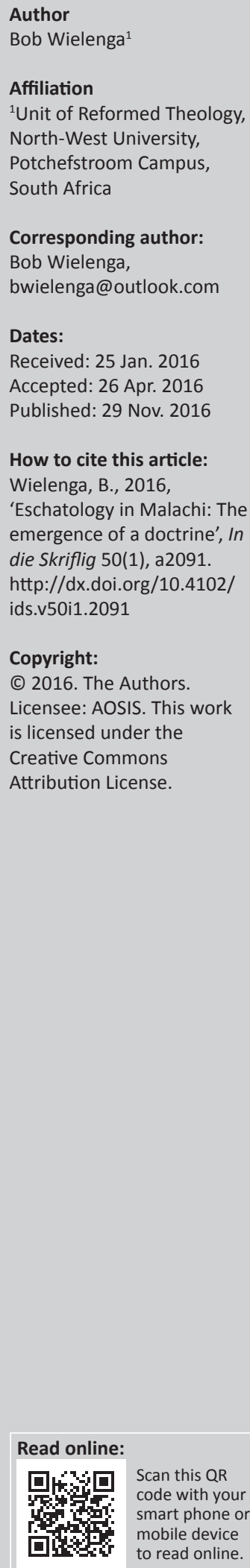

\begin{abstract}
In this article the eschatology of Malachi is investigated within its own historical context. The socio-political and spiritual situation of the early postexilic Persian era in Yehud is briefly outlined. The attention is then focused on the prophetic voices which articulated eschatological visions at that point in time. This article's contention is that Malachi's eschatology had developed from that of Haggai, being influenced in the process by the eschatological insights of Zechariah and 3 Isaiah. The conclusion is that in Malachi Haggai's proclamation of eschatological hope is confirmed, albeit adjusted by the introduction of divine judgement into his eschatological discourse in response to the community's disappointment at the perceived delay in the fulfilment of the promised future.
\end{abstract}

\section{Introduction}

The present research takes as its point of departure Haggai's eschatological prophecies in 2:6-9, 20-23. The time period under review is demarcated on the one hand, by the year of Haggai's prophecies in 520 bce, and on the other hand, by the arrival of Ezra in Jerusalem in 458 bce. Scholarly consensus is that Malachi was in action as prophet before Ezra's arrival, and that his book must have been composed before that time.

The question to be answered is what came of Haggai's positive message about the eschatological future of Yehud, centred on the reconstructed temple as focus point of a pacified world at peace with the God of Israel $(\mathrm{Hg} 2: 6,9)$ ? Within half a century of the completion of the temple (516 bce) defeatism and disillusionment had the upper hand in the sparsely populated, politically oppressed and socio-economically depressed Jewish society. The fulfilment of the promise of hope ('in a short while' - Hg 2:6) seemed to be indefinitely delayed, if not cancelled. In the book of Malachi, a comprehensive response is found to counteract this spiritual negativism, which affected the whole of life, beginning with the temple cult. The reasons for the delay are identified, while the eschatological hope is firmly confirmed, albeit in an adjusted form. This adjustment refers especially to Malachi's introduction of divine judgement into the eschatological discourse, an issue rather missing in Haggai's eschatological prophecies. Malachi has been influenced by the prophetic voices of Zechariah and 3 Isaiah at this specific point in his eschatological message. One can speak of a development in the eschatological discourse from Haggai's till Malachi's time. Possible influences from pre-exilic or exilic prophets will not be investigated.

The definition and methodology of prophetic eschatology is contested without too much scholarly consensus around the term and its concept (Grabbe \& Haak 2003). As clarification of the way the term is understood in this research, prophetic eschatology remains within the boundaries of thisworldly history, integrating God's future interventions for the sake of Israel and the nations in this world into the structures of space-time history. This is done in distinction from apocalyptic eschatology which reaches imaginatively beyond the realm of this world into an other-worldly reality (Collins 1987; 2003:74-84), even though the differences between both types of eschatology must not be exaggerated (Cook 1995; 2003).

\section{Outline and methodology}

Firstly, Haggai's eschatological vision ( $\mathrm{Hg} 2: 6-9,20-23)$ is summarised, after a brief sketch of the social-political and religious context of the early Persian era in Yehud. Secondly, the focus shifts to Zechariah's possible influence on the eschatological discourse as developed by Malachi, while the scribal prophecy 3 Isaiah is taken into account as well. The inclusion of both prophetic voices is based upon the historical and intertextual links between them and Malachi (Blenkinsopp 2003; Floyd 2002:415-421; Seitz 2004; Stromberg 2014). Thirdly, Malachi's own eschatological message is theologically assessed against the background of the historical development of the eschatological discourse in Yehud in the early Persian era. 


\section{The time of the prophet}

Firstly, the socio-political context of Malachi is outlined; secondly, attention is paid to the faith traditions dominant in his time and age.

\section{The historical situation}

Scholarly consensus has grown around the dating of the ministry and book of Malachi between 516-458 bce (Hill 1998:75; Pierce 1984). ${ }^{1}$ Malachi reflects the same historical and theological background as Zechariah and 3 Isaiah. Politically, the returnees from exile were subjected to the Persian Empire, and hardly survived as a rural subsistence economy, burdened as they were by heavy taxes to be paid to the imperial administration. In addition, in Malachi's time the countryside was ravaged, again by droughts and later also locusts (Hg 1:5-6, 9-11; 2:15-17; Ml 3:10-11). The smallish Persian province of Yehud numbered approximately 20-30 thousand inhabitants at most, and were vulnerable to the threat of external and internal enemies (Floyd 1999; Lipschitz 2003:364; Vandenhooft 2003:235-262). Malachi's ministry assumes a functioning temple cult (post-516 bce). A considerable part of his book is dedicated to a biting critique of this cult and its officials (Ml 1:10). The renewal and reconstruction programmes, instigated by Ezra and Nehemiah (Wielenga 2013:1-5), are not yet anticipated, even though, partially, both reformers addressed the same social and religious ills that were found in Malachi's time (Ezr 8-10; Neh 5; 13).

In short, roughly between 516-458 bce Malachi must have entered the scene of the suffering remnant population of Jews, disillusioned and disappointed by the circumstances they found themselves in, which they ascribed to a God not interested in what was happening to his own people (Ml 2:17). The eschatological fervour, ignited by Haggai, and confirmed by Zechariah and 3 Isaiah, had long died down.

\section{The theological context}

The faith traditions that Malachi shared with his prophetic colleagues, could be characterised in essence as, covenantal. The pre-exilic covenant theology as developed in Deuteronomy (Block 2012; McConville 1984; Miller 1990: 10-16) also finds expression in Malachi (Assis 2012:212-219; McKenzie \& Wallace 1983:549-563; O’Brien 1990:85-107 and Weyde 2000:37-47). The covenant, known for its asymmetrical mutuality (unilaterally established by the sovereign God (Ml 1:6) and bilaterally maintained by God in cooperation with his faithful people), ${ }^{2}$ was breached by the people on two accounts.

Firstly, the theological basis of the covenantal relationship was undermined. God's presence among them in the temple

1.For a different view, see Weyde (2000:12-23). Tiemeyer (2005:178), among many others, is followed here, accepting the prophet as a historical figure whose oracles have been collected, edited and published in levitical circles not too long after the closure of his ministry (Hill 1998:54), but before Ezra appeared in Yehud in 458 bce.

2.See Wielenga (2014) for the recent discussion on the mutuality of the covenant; McKenzie and Wallace (1983:549-563) for the discussion on the conditionality of the covenant in Malachi. was threatened by their apathetic worship. Malachi's harsh criticism of the temple staff and their mismanagement of the crucial sacrificial cult (Ml 1:6-2:9) is in stark contrast with Haggai's eschatological focus on the temple, and Zechariah's emphasis on the significance of a pure temple community under the leadership of a divinely cleansed high priest (Zch $3: 1-7)$. The severe critique of the spiritual and social condition of the nation, found in 3 Isaiah, confirms Malachi's stance.

The spiritual force behind this ritual decline is pointed out in Malachi 2:5-7. The original calling of the priesthood to revere God's name, to instruct the people in the law of Moses, and to turn them away from sin had been corrupted. ${ }^{3}$ As 'messenger of the Lord Almighty' (O'Brien 1990:42; Weyde 2000:199-203) the priest had an authoritative mediating role to play between God and his people. But the priests violated their calling and led the people astray. Their running down of the sacrificial ministry in the temple is decried by Malachi as a blasphemy of God's name. The breaking of 'the covenant with Levi' resulted in the nonpayment of the tithes to the temple (Ml 3:6-12), understood by Malachi as a robbing of God (Assis 2010:359). The people's apathy in the execution of their covenantal duties had been aggravated by the priests' failure to keep God's 'covenant with Levi'. This apathy stood in sharp contrast with their eagerness to do all what God had forbidden in the law of Moses (cf. also Is 56:9-57:13; 59:1-20).

Secondly, the males in the community came in for harsh criticism: some got married outside the faith to the daughters of a foreign god (M1 2:11-12), while some others divorced the wives of their youth to do the same (Ml 2:13-16). ${ }^{4}$ Their dire economic circumstances and perceived lack of social security caused them to marry into the ranks of established families of their heathen neighbours or of the syncretistic Samaritans (Snyman 2006:30). Malachi censured this as a desecrating of God's dwelling place among them, a 'detestable' thing to commit (Ezr 9:11; 10:17; Ml 2:10-11). It boiled down to a breaking up of God's covenant concluded with the fathers (Ex 2:24; 19-24), destabilising the small-scale Yehud society as well (Hill 1998:258; Snyman 2014:600). Especially the raising of the offspring in the ancestral faith $(\mathrm{Ml} 2: 13,15)$ was at stake here (see Kottsieper 2007:95-124 on Neh 13:23-28). Their continued worship in the temple became therefore futile (Ml 2:12-13).

In conclusion, the coherence of God's covenant people was under threat as direct consequence of the ill-functioning temple cult, aggravated by the many socio-economic ills (Ml 3:5) that should have reminded them of the prophetic rebukes from before the exile (Zch 1:2-6; 7:1-14). Their mistrust of God and his promises (Ml 3:14) made them apathetic in their worship and negligent in their obedience, unchecked by the deficient teaching ministry of the priests.

3.This original calling of the priesthood is described in the text with the term "the covenant with Levi' (Hill 1998:173-212; O'Brien 1990:104-105; Weyde 2000:193194). See also De Jong (2002:99-100).

4.See Glazier-McDonald (1987a:603-611); O'Brien (1996:247-248); Zehnder (2003) for the question whether to read Malachi 2:10-16 literally or metaphorically. 


\section{From Haggai to 3 Isaiah}

In the following section the development of the eschatological discourse in the early Persian era are outlined. Previous research into Haggai's eschatology (Wielenga 2015:1-13) will be briefly summarised to form the basis for the following discussion.

\section{The prophet Haggai}

Haggai announced that 'in a little while' ( $\mathrm{Hg} \mathrm{2:6)}$ the heavens and the earth would be shaken by the Lord Almighty, and the political world map be redrawn by him. The nations would pilgrimage to the rebuild temple and would bring glory to the Lord Almighty together with the people of Israel. Peace would spread out from the temple, the centre of the world. In the turmoil of the times ahead God would look after his people like a king looks after his signet ring ( $\mathrm{Hg}$ 2:20-23; Goswell 2010:77-90; Rose 2000:208-247). As pointed out, in Malachi's days this vision had lost its lustre and appeal; the people had lost hope that this eschatological promise would be fulfilled soon, if ever.

Theologically Haggai's eschatological vision can be analysed as follows. It is rooted in the covenantal promise of God to his people in the redemptive past (Ex 2:24; 19:1-24:18) to always be their God. This promise anchors the future of God's people throughout history, and through them the future of the world (Wright 2006). This promised future, entrenched in the redemptive past, shapes the present in which the people had to live in the presence of God, who dwelled among them in the temple of Jerusalem. Therefore they had to break with their sins committed in times gone by (537-520 bce), and be committed to God and his promised future, which would arrive in his time and according to his good pleasure. Their turnaround should be demonstrated by their rebuilding the temple but also the temple community (Zechariah's focus). On their journey from the present into God's future the people were assured of God's providential care, and could already fragmentarily anticipate the peace they had to wait for with patient impatience.

\section{The prophet Zechariah}

Because of the constraints of this article the focus will be only on Zechariah 7-8 (Boda 2003:390-406; Kashow 2013:385-403), and Zechariah 14 (Floyd 2002:401-422; Rose 2012:183-196; 2013:213-230).

The unity between Zechariah 7 and 8 which play a crucial role in connecting Zechariah 1-6 with 9-14, must be maintained (for a different view, see Assis 2012b:17-18; see, however, Boda 2003:395-397). In Zechariah 7-8 reasons are given why the future, promised in 520 bce by Haggai, has not yet arrived (Zch 1-6). Subsequently these chapters introduce Zechariah 9-14, where this delay in fulfilment is elaborated upon from an eschatological (and apocalyptic, cf. Cook 1995:123-166) perspective.
The literary cohesion of Zechariah 1-14 is assumed in this article; the different sections (Zch 1-8; 9-11; 12-14) are also theologically interlinked. ${ }^{5}$

\section{Zechariah 7-8}

In Zechariah 8 the eschatological promise of hope, expressed by Haggai, is confirmed. A bright future of peace and prosperity is drawn up for Jerusalem, where powerful nations will also worship God together with Israel (Zch 8:20-23). But this promise will only be fulfilled after true spirituality has been restored (Zch 8:15-16). The theme of true spirituality belongs to the hard core of Zechariah's (1-8) prophecies (Zch 1:2-6; 7:4-14). This is what God wanted to see at work behind the temple building project, but in the consultation about the fasts as well (Kashow 2013:392-393). The lack of true spirituality is pointed out in Zechariah 7:910 , where social ills are mentioned. Even the priests indulged in feasting instead of fasting (Zch 7:4). The ritual cleansing and reconfirmation of the high priest's ordination (Zch 3:1-7) was needed, considering the reality of a failing priesthood. Different from his contemporary Haggai, Zechariah confronted the present generation with the sins of the previous, pre-exilic ones. The words of the earlier prophets were recalled (Zch 7:7-13; 1:4-6): words of warning and judgement which had been fulfilled in the exile. In line with the pre-exilic covenant theology, God kept his promises of blessing, but also of judgement (Lv 26; Dt 28; Block 2012 on Dt 28). Eschatological promises of hope were not fulfilled as if they were futurological predictions. Promises were related to the obedient commitment of God's people to God's law (Kashow 2013:400-403). As pointed out this covenantal theology was also still dominant after the exile.

The eschatological promise of hope for the future is confirmed, but the manner of fulfilment has been adjusted. From now on the future would arrive through and beyond judgement of God's people. New in Zechariah's prophecies as well is his reference to an end-time figure, the Branch, who will play a decisive role in establishing the eschatological future, as seen in Zechariah 3:8-9; 6:12-13 (Rose 2000:142-176; 2013:216-218).

\section{Zechariah 14}

In Zechariah 9-14 the theme of the eschatological future is taken up again and elaborated upon. Apocalyptic influences can also be noted. ${ }^{6}$ Even though Haggai's eschatological message of hope for the future is confirmed, in these last two sections of Zechariah too the promised future will be arrived at through judgement (Zch 14:1-2, 3-7).

In Zechariah 12:1 the hope is raised of the renewal of the world order by God the Creator, known in Israel as the Lord God Almighty. As the Commander-in-chief of the heavenly

5.It is interesting to note the influence of Persian archer imagery in Zechariah 9 (Bonfiglio 2012) and of Old Persian inscriptions with regard to the creation formula in Zechariah 12 (Mitchell 2014). This makes an early date for the two final sections plausible.

6.See Zechariah 14:6-7, 8-11; cf Isaiah 60:19-20; Revelations 21:23; 22:5; cf. Van der Woude (1984:259-262); Westermann (1969:364); and Cook (2003:99-105). 
hosts he is in control of world history (Zch 9:14-17; Rose 2012:186). And as the divine warrior (Bonfiglio 2012:507-527) he will do battle on behalf of his people; the political world map will be redrawn, and world peace will be established around a restored Jerusalem, where God will dwell in his temple, worshipped by Israel together with the nations (Zch 9:16-17; 14:8-21). Just like Haggai, Zechariah too describes God's eschatological intervention on behalf of his people with the image of the shaking of the cosmos, but now with the Mount of Olives as its epicentre. A climate change will take place, while the land receives a facelift (Rose 2013:226; Zch 14:3-10; see Hg 2:6-9, 20-23).

Differently from Haggai, Zechariah introduces warfare imagery, associated with the Day of the Lord, known from the pre-exilic prophetic traditions (Lessing 2010:253-257; see also Boloje \& Groenewald 2014:53-81; Bonfiglio 2012). This underlines the extreme seriousness of the advent of the Day of the Lord both for Israel and the nations (Zch 9:2-8, 14-17; $12: 2-13 ; 14: 1-7,12-15)$. Again the emphasis is upon what the Almighty will do for his people on that day (Zch 10:3-12), but redemption will come through judgement (Zch 14:2), and not without it.

The Lordship of God as King over the whole earth (Zch 14:9) will be announced on that day (Rose 2000; 2012:191-192; 2013:213-229). An identification of this King with the Branch (Zch 3:8-9; 6:12-13) ${ }^{7}$ is likely. But God's Lordship as King will be established in a completely unexpected way, which suggests at least a contradiction between the status of the King and his modus operandi (Zch 9:1-8, 9-10; 12:10). ${ }^{8}$

In summary, Zechariah confirms on the one hand Haggai's eschatological message (Zch 1:7-17; Tollington 1993:227-228). On the other hand, he elaborates on it by adding new elements, not touched upon by Haggai. Thus he lays the platform from which Malachi can launch his withering attack on a nation which had lost hope in God's future.

\section{The scribal prophecy of $\mathbf{3}$ Isaiah}

In this article there is no need to go into the complicated discussions within Isaianic scholarship with regard to the literary composition and thematic unity of this book and especially of its third part (Is 56-66). ${ }^{9}$ Consensus is growing around the categorisation of 3 Isaiah as scribal prophecy (Blenkinsopp 2003:37-39; Stromberg 2014:211). Its postexilic scribes based their written texts upon the scriptures, which came to them authoritatively in oral or written form, in 1 and 2 Isaiah. With a view to the present time they read and interpreted its message, which became reconfigured in the process. ${ }^{10}$

7.Rose's (2000) interpretation of the Branch-texts (not to be identified with Zerubbabel) is followed here (Wielenga 2015).

8.In the New Testament this modus operandi is elaborated upon in Philippeans 2:5-11.

9.Apart from the commentaries, see Beuken (1990), Kraus (1966), Venter (2012) and Dekker (2015).

10.See Stromberg (2014:195-218) for this process.
Attention will now be paid to two interrelated themes developed especially in 2 Isaiah that found their reconfiguration in 3 Isaiah. They are relevant to the understanding of Malachi's eschatology. Firstly, the divine promise of hope for the eschatological future is discussed and secondly, Israel's identity in that future is also scrutinised.

\section{Hope for the future}

Relevant to this discussion about the eschatological future is the emphasis given in Deutero-Isaiah to the new things God is going to do in the near future (Is $42: 9 ; 48: 6-9$ ). The return home from Babylon is compared with the first exodus, one of the former things (Is 43:18-19) which will now be surpassed by this second one back to Jerusalem, where God would dwell and manifest his glory in the reconstructed temple (Is $46: 13 ; 48: 20-21)$. Even though the people neglected their worship of God during exile, they were called to forget the former things, and to open their eyes for the new things God is going to do (Is 43:18-19; 55:12). The return from exile was just the beginning of the new things to come.

It is plausible (Beuken 1979:129-130; Koole 1985:142, 165-166) to include in the new things to come the ministry of the Servant of the Lord, as announced in Isaiah 42:1-9; 49:1-13; 50:4-11; 52:13-53:12. ${ }^{11}$ In establishing the new era, the Servant will play a central role (Is $42: 7 ; 49: 6$ ).

In 3 Isaiah a different context is presumed, historically and theologically, in which the authoritative Word of God in Deutero-Isaiah was read and appropriated in a new way to meet the anguish and concerns of the smallish Jewish population in Yehud. Within this community two views of the future were found. The majority view is spelled out in Isaiah 59:1. In the present situation of economic hardship, political oppression and social strife (Berquist 1995; Lipschitz 2003) the people's trust in God's promises has failed, even though they carry on with their ritual duties (Is 58:3, cf Zch 7:1-3. Blenkinsopp 2003:182). The minority voice can be heard in the penitential prayer of Isaiah 63:7-64:12 (Boda 2015:75; Venter 2012:1-12). Against all odds, they confess God as their Father, their Redeemer of old; their request to him is to return for their sake (Beuken 1986:14), 'the tribes that are your inheritance' (Is 63:16-17). How is the message of hope presented in this conflicted situation?

Firstly, the promise of hope as spelled out in 2 Isaiah, is confirmed in Isaiah 60-62 which forms the core of 3 Isaiah (Kraus 1996:320). ${ }^{12}$ In spite of the sinful tendencies of the people (idolatry, syncretism, and corrupt social behaviour; Is $56: 9-57: 12 ; 65: 1-7)$, the promise of a glorious future is going to be fulfilled (Is 62:1-12), although this future is now reconfigured and eschatologised in order to address the seriousness of the situation. The people are urged to be on the lookout for signs of the advent of God Himself in the city with peace in his wake. They are called watchmen - an

11.It is impossible to do justice to the extensive body of literature written on these Servant Songs (Wielenga 1998:109-118).

12.For the literary composition of 3 Isaiah, see Stromberg (2014:208); Westermann (1969:296-299). 
indication of their sacred duty to be constantly on their guard and report immediately any evidence of God's royal arrival. In Isaiah 63:1-6 the watchmen are seen in the gate in discussion with the divine warrior (cf Zch 9:14-15) still dripping with blood from his royal battle with Edom (Cook 1995:89, 174), used here as chiffre representing all nations with an Edom-mentality, as expounded in Malachi 1:2-5 (Blenkinsopp 2003:238; Koole 1995:299-300; Mudde 1990: 33-36). His battle was all about righteousness, the basis for a new world order in the future (Koole 1995:318 Mudde 1990:33-36 319). In short the promise of hope for the future is strongly confirmed in Isaiah 60-62.

Nevertheless, in Isaiah 60:1-3 a new element is introduced into the eschatological discourse. In this passage light and darkness are intertwined, referring to redemption, but also to judgement, which will come upon God's people and the nations (Mudde 1990:66-67). On the one hand, God's light and glory will shine in Zion attracting the nations to Jerusalem to worship him together with God's own people (Is 60:4-11; 61:11). Peace will reign over Jerusalem (Is 60:13-21): its gates will always stand open and no enemy is in sight (Is 63:11; cf Zch 2:5). But on the other hand, judgement will come upon those nations that are not interested in pilgrimaging to God in Zion, and that are unwilling to serve his redeemed people (Koole 1995:241-242). In Zechariah 14:16-19 one finds a similar message (Mudde 1990:75).

Secondly, the judgement is also extended to God's own people. This is already indicated in Isaiah 61:1-2, where a year of the Lord's favour is announced, but a day of God's vengeance as well (Peels 1992:133-136). Not only will the nations face his vengeance, but the majority of God's people as well. It is for that reason that the people who will share in God's eschatological future are carefully portrayed by the prophetic voice in Isaiah 61:1. They are clearly told apart from those who will be excluded from the promised future. They are crushed by their fellow citizens (Is 57:1; 58:6-7), socially vulnerable and in need of a programme of upliftment as designed by the legislation surrounding the Year of the Jubilee (Lv 25; Blenkinsopp 2003:251). They are described as well as the broken hearted who mourn and grieve in Zion and tremble for God's Word (Is 61:2-3; cf 57:15; 66:2; Dekker 2015). They are the people who raised their voice in penitential prayer to God (Is 63:7-64:12). Their fellow citizens who are oppressing them will perish under God's vengeance together with the 'Edomite' nations (Peels 1992:130-141). ${ }^{13}$ The day of vengeance is the day of redemption, or the year of God's favour for these crushed ones who will receive a new name (Is 62:12) and become part of the everlasting covenant (Is $61: 8$ ), being heirs of the promised future (Is 65:17-25). Based upon the authors' appropriation of God's authoritative Word in Isaiah 42:7, it is plausible in Isaiah 61:1-2 that in their opinion, the Servant of the Lord will have a hand in the realisation of the coming future (Dekker 2015).

13.For God's vengeance, see also Isaiah $59: 15 \mathrm{~b}-20 ; 63: 1-6$ where He is portrayed as divine warrior inflicting vengeance on his foes, the nations and his own people as
well (Koole 1995:178). Blenkinsopp (2003:225) incorrectly maintains that God's judgement does not play a role in Isaiah 60-62.

\section{Identity in the future}

A shift in the definition of who God's people are can be observed in the penitential prayer of Isaiah 63:7-64:12 (Blenkinsopp 2003:266; Koole 1995:381; Venter 2012:1-12). ${ }^{14}$ The crushed people, putting their trust in God (Is 61:2-3), end that prayer with the plea to God to return for the sake of his servants, the tribes of his inheritance (Is 63:17). They speak of themselves as 'all of us' (Is 64:6), and 'all your people' (Is 64:9). In his reply to this prayer in Isaiah 65-66 (Boda 2015:75; Stromberg 2014:208), God distinguishes among his people between his servants who seek him (Is 65:8-10) and those who forsake him (Is 65:11-12). An unbridgeable gulf appears between those two components of the community of the returned exiles (Is 65:13-16; Beuken 1990:76-78). Those who claim God for their Father and hope for his redeeming intervention on their behalf, stand opposed against those who depend only on Abraham as their biological father, who, however, would not recognise them anymore as his covenantal offspring (Beuken 1986:10-11; Koole 1995:349, 355. For a different view, see Bautch 2009:48). Not all who descend from Abraham belong to Abraham! The faithful minority of the people stands for all Israel. ${ }^{15}$

It is possible that, as Dekker (2015) argues, the identity of God's people of the future becomes blended with that of the Servant (Beuken 1990). God as the high and lofty One dwells among his crushed people in order to revive their broken spirits (Is 57:15). At the same time, he shares his high position (Is 6:3) with his Servant, through whose ministry he will bring peace and healing (Is 53:5), and secure their future (they will see their offspring; Is 53:10). In one way or another, God is going to involve this mysterious Servant in his eschatological plan for the future. This opens also the way for the nations to join God's people, which will consist of the faithful remnant of all Israel, plus those of the nations who come in pilgrimage to God in Jerusalem (Is 42:6; 49:6; Blenkinsopp 2003:311-315).

According to Isaiah 66:18-19, 'missionaries' from the own ranks of the nations will proclaim God's glory among them before the eschatological judgement will come down upon all men. This opens the way for them to make the pilgrimage to God in Zion. It could be that, based upon Isaiah 42:4; 49:1 and 52:13-15, the Servant will be involved in this ministry as well. The suggestion is certainly there.

\section{Summary}

At this point it is good to take stock of the discussion so far. Do the results of the investigation in Zechariah and 3 Isaiah show indeed that the eschatological discourse since Haggai has been progressing in one way or another?

Firstly, in Zechariah and 3 Isaiah Haggai's eschatological vision $(\mathrm{Hg} 2: 6-9,20-23)$ is endorsed with regard to the new

14.About this passage as penitential prayer or lament, see Tiemeyer (2014:102-122) There is an allusion here to Lamentations 5:22.

15. For a discussion of the remnant-concept in the Old Testament, see De Jong (2002:110-121). 
world order centred around the temple in Jerusalem (Is 62:1-12; 65:17-25; Zch 8:1-8, 20-23; 14:8-21). They address the problem of the perceived delay in the fulfilment of this promise, made in 520 bce. The lack of a true, covenantal spirituality among the majority of the community is pointed out as the cause of the delay. Hence divine judgement is introduced into the eschatological discourse; the warfare imagery, associated with the Day of the Lord prophecies, however absent in Haggai, is now fully employed (Is 63:1-6; Zch 14:3-10). This eschatological judgement is aimed at the nations, oppressing God's people, but not less at God's people themselves (Is 59:15b-20; 61:2; 63:1-6; Zch 9:2-8).

Secondly, the identity of God's people is reconfigured in the process. Having survived judgement, they represent 'all Israel', and are included in the covenant (Is 61:8; 63:16-17). Their new identity is inclusive, including those of the nations who have been 'missionised' by people from their own ranks (Is 66:18-21), and have responded to their call to pilgrimage to Zion.

Thirdly, in Zechariah and 3 Isaiah end-time figures appear on the eschatological scene to make the promised new things happen, even if their identity remains enigmatic. This clearly differs from Haggai, who does not introduce an end-time figure in his eschatological discourse. ${ }^{16}$

In summary as in Haggai, in Zechariah and 3 Isaiah the eschatological future is anchored in the past of the redemptive history of God with his people and shapes the present, in which they have to live in God's presence. The introduction of divine judgement into the eschatological discourse aims at the transformation of the people in the present in preparation for the promised future. At heart, all three prophets are one in their trust in God's covenantal faithfulness as the hard core of their eschatological hope.

\section{Malachi's eschatology}

The focus of the investigation in Malachi's eschatology will be on Malachi 2:17-3:7a; 3:13-21; 3:22-24. There is no scholarly consensus around the interpretation of Malachi 1:5, 11 , and 14; it would take too much space to do justice to the discussion of these texts. ${ }^{17}$ They are left out of the following discussion. The texts under investigation will be read in the context of Malachi's own time, in which Haggai, Zechariah and ' 3 Isaiah' also lived and worked.

\section{Malachi 2:17-3:7a}

In Malachi 3:1-7a ${ }^{18}$ the accusation of the people, 'Where is the God of justice?' (Ml 2:17) is refuted. The prophet's response is

16.See Rose $(2000: 208-247)$ for the non-messianic interpretation of the Zerubbabeltext in Haggai 2:20-23.

17.For a hyperbolical interpretation, see Viberg (1994); for a non-eschatological one, see Van der Woude (1982); Weyde (2000); and for an eschatological one, see Baldwin (1972); Goswell (2013); Hill (1998); Snyman (2004); Verhoef (1972). An Baldwin (1972); Goswell (2013); Hill (1998); Snyman (2004); Verhoef (1972). An to Zion as conceptualised in Haggai, Zechariah and 3 Isaiah.

18.Snyman (2011:156-168) argues with good reasons, for a demarcation of Malach 2:17-3:7a instead of the usual 2:17--3:5. This has consequences for the interpretation. clear (Ml 3:6): God did not change; He is still the God of justice. He is already approaching them in judgement, which is imminent. The first to experience his wrath would be the temple staff, who had defiled the sacrificial ministry of the temple (Ml 1:6-2:9). This judgement is described in terms of purification of silver by a refiner (Zch 13:9; Ml 3:2-4). Portraying divine judgement in this way signifies that it is not yet final and definite (Ml 3:6b). It has a salvific goal: through judgement the temple worship will be restored up to the Mosaic standards ( $\mathrm{Ml} \mathrm{3:4)}$ ) as the beginning of the turnaround of the whole nation (Boloje \& Groenewald 2014:69). In conclusion the people will be judged because of their persistent disobedience to the law of the covenant (Ml 3:5). But hope of salvation is kept alive: return to me, and I will return to you, says the Lord Almighty.

This concurs with the message that God had already sent ahead his messenger, who would prepare his forthcoming arrival as judge. Not much agreement is found among scholars about the identity of this messenger, and of the other two figures mentioned: the lord ( $h a^{\prime}$ adoon), and the messenger of the covenant ( $\mathrm{Ml} \mathrm{3:1)} .{ }^{19}$ The allusion to Isaiah 40:3 and 57:14-21 makes a metaphorical explanation of this messenger's preparation work plausible (Koole 1995:115-120; Westermann 1969:327-328). Judgement is announced (Ml $3: 1 b, 5)$, but a time of grace is inserted as well, in which the messenger will carry out his mission, addressing the sins of the people, to begin with the temple staff, and warning them to take God's judgement seriously. True repentance, preached by the messenger, would open a path through judgement towards salvation beyond. ${ }^{20}$ Judgement as total destruction is what the messenger tries to prevent. ${ }^{21}$

The identification of the messenger, preparing God's arrival at his temple, with a non-messianic, ${ }^{22}$ prophetic figure seems the best option to follow (McKenzie \& Wallace 1983:554; Snyman 2006:1041-1044). Malachi himself could be considered as model for such a messenger, bearing in mind that his name means my messenger. Snyman (2006:1032) is probably correct in proposing Malachi 3:1a as a later editorial insertion in the text, caused by the need to explain the perceived delay in the fulfilment of God's promise of judgement. The delay is then interpreted as a time of grace, in which prophetic figures like Malachi were given space and time for their ministries to bring about a renewal and revival of the people. It does not seem unlikely to single out Ezra and Nehemiah, starting their ministries shortly after Malachi, as candidates for this messenger role during the inbetween times before divine judgement would occur.

19.Cf. Glazier-McDonald (1987b:133-135); Hill (1998:287); Miller (2007:3-7); Snyman (2006:1031-1045); Van der Woude (1982:130-131); Weyde (2000:289-290.

20.0'Brien (1990:44) and Snyman (2006:1037-1039) identifies the ha'adoon in Malach $3: 1 \mathrm{~b}$ as the Lord, while the messenger of the covenant in Malachi 3:1c is functionally identical with the Lord, stressing that his judgement will aim at the re-establishment of the covenant with Levi (2006:1040-1041). See also Malchow 1984.

21.In a different view from Boloje and Groenewald (2014:68-69), the ha'adoon must be seen as the agent instigating and carrying out the purification (O'Brien 1990:44, with reference to Ezk 37:23).

22.For the non-messianic option, see Blomberg (1987:103-105); Keown (1987: 443-451) and Miller (2007:13-14. For a different view, see Boloje and Groenewald (2014:68) 
Their administering of the law of Moses was the means by which they carried out their divine calling (Ml 3:22).

As already is mentioned, no indications of a messianic interpretation of the messenger in Malachi 3:1a can be found. ${ }^{23}$ One might rather suggest that the messenger of the covenant who intends to restore the covenant, and thereby a pure temple worship with Levi, has messianic features. But this cannot be distilled from the Malachi-text.

To be noted is that eschatological language is employed here, known from pre-exilic traditions (Jl 2:1-11; Am 5:18-20; Zeph 2:14-18; Rendtorff 2011:704-705). In the same tradition stream we find Zechariah after the exile (9:14-17; 12:2-13; 14:1-7, 12-15), followed here by Malachi. The fulfilment of the eschatological prophecy is urgently desired, and has to be imminently expected, as is articulated in Malachi 3:1a+b: 'unexpectedly' the Lord (ha'adoon) will come to his temple, preceded by the messenger he has already sent to prepare his way. The date of the Day of Judgement is not mentioned, but it is mentioned how hard that day will be to endure, when he appears as Judge (Ml 3:2).

\section{Malachi 3:13-21}

In this passage the people's accusation also is refuted: it is not futile to serve God and to obey his requirements; it is not true that evildoers prosper and escape judgement (Ml 3:14-15). These accusations are born out of the dismal conditions of the community and are proof of a spirituality gone wrong. But a turnaround in their condition is announced by God, introduced with a narrative unit in Malachi 3:16 (Weyde 2000:360-362). The turnaround will take place on the Day of the Lord (Ml 3:17-19), and will cause a division between those who fear the Lord (Ml 3:16) and the wicked who do not serve God (Ml 3:18). The first group will continue to trust the Lord and their names will be remembered by God (Ml 3:16); they will enjoy the eschatological peace, basking in the sun of righteousness, which will rise with healing in its wings (see in this regard Is $30: 26 ; 53: 5 ; 58: 8) .{ }^{24}$ But for those who persist in their arrogance towards God and in their evil behaviour (Ml 3:19) that day will come burning like a furnace; nothing of them will be left. This judgement is total and definite in contrast with the judgement announced in Malachi 3:2 and 5, where it is compared to a refiner's fire. A purified temple staff and worship will be the result around which a transformed nation of God-fearers could develop (Snyman 2014:608).

In Malachi 3:17-21 the Day of the Lord stands central as the final conclusion of history. Weyde (2000:366-368) points out that that day itself is subject to the destruction of all that is evil. Again no temporal indicators are given. The imminence and urgency of that day is implicit now as well; no time schedule is provided. The emphasis is upon heeding the warning and acting upon it accordingly, as the time of grace is still in place.

23.For Ben Sira 48:10, 4 Q521 and the LXX, see Bauckham (2008:330-335); Miller (2007:7-11); and Öhler (1997:5-17). See Blomberg (1987) and Malone (2006) as well.

24.For the ANE symbol of a winged Sun Disc, see Hill (1998:350); Glazier-McDonald (1987b:239); Van der Woude (1982:153-154); and Weyde (2000:373).
The question is whether Malachi is speaking here (Ml 3:2-5 and 3:19) about one day from two distinguishable perspectives (Verhoef 1972:265), or whether the two days take place at different moments in time, each with its own significance but interrelated (Van der Woude 1982:134). It seems more likely that the two defining aspects of the Day of the Lord are stressed. The salvific aspect is put across in the image of a refiner's fire, and the destructive aspect is visualised in the image of a burning furnace (Petersen 1995:224). There is hope for those who tremble at God's Word; there is no hope at all for those who disregard God's Word, as contained in the law of Moses (Mal 3:5; 3:22). The announcement of the Day of the Lord functions as a wake up call and a clear sign that God still loves his people (Ml 1:2-5; 3:17), undeniably albeit not indiscriminately (Snyman 2014:599-600).

\section{Malachi 3:22-24 // 4:4-6}

That Malachi 3:22-24 is a very deliberate addition by a later hand to the book it is attached to, but also has to be considered as conclusion to the Corpus Propheticum and the Old Testament canon as a whole, seems plausible (Assis 2011a: 207-209; 2012:3; Petersen 1995:232) ${ }^{25}$ Chapman (2000:139-145) could be right in describing Malachi 3:22-24 as scribal prophecy, in which the faith traditions of Israel, as found in the law and the prophets are seen as representing 'complementary dispensations within a single economy of Israel's God'. ${ }^{26}$ Here only the function of this passage as conclusion to the book of Malachi is studied.

In this time of crisis, the people were admonished to remember (Assis 2011:209-210) the teachings of Moses ${ }^{27}$ with regard to the service of God, indicating that they had not only to observe those teachings outwardly, but from the heart (Dt 4:9-10, 29; 6:4-5; 10:12-13). At the same time they had to await the eschatological future which would break in with the arrival of the prophet Elijah before God's final Day. That day would bring destruction for the wicked to be burned like stubble in the fire of a burning furnace, but acceptance to those who tremble at his word with a love like the warmth of the sun rising with healing in its wings. The task set out for Elijah to perform in the future, turning the hearts of the fathers to the children, and those of the children to the fathers ( $\mathrm{Ml} 3: 24)$, is illustrative of the great social reversal which will take place in the eschatological era. Against the background of the ancient Near Eastern literature (Kruger 2011:638-645; Van der Woude 1982:159) it is almost a standard literary convention to describe the devastating chaos of the whole of society as a total collapse of ancient family structures. Their restoration is seen as a sign of the eschatological future, the core of a newly

25.Assis (2011); Landy (2011); Snyman (2007; 2012; 2015) and Van der Woude (1982) discuss this in connection with the intentional place of Malachi within a deliberately constructed Book of the Twelve Prophets. See also Chapman (2000:141).

26. It is unlikely that the emphasis on the law of Moses in Malachai 3:22 is intended by the final editor to close the prophetic era in favour of a Torah dominated religion (cf. Chapman 2000; 2003).

27.There is no consensus on the question what is meant with the law of Moses. With Chapman (2000:144) one could speak here of a canon-conscious ending, assuming one written form of the Pentateuch or another (Wielenga 2013:3-4). See also Boloje and Groenewald (2015:3-4). 
stabilised and peaceful society. In the present the past and the future of redemptive history are coordinated in two prophetic figures dominating Israel's history, Moses and Elijah, representing the law and the prophets, who had to guide them in the present towards the future.

That just these two personalities, Moses and Elijah, are mentioned here, makes sense in view of the Deuteronomistic traditions, that are alluded to in this passage (GlazierMcDonald 1987b:246-247; Kruger 2011:630-634). The redemptive history narrated in the Old Testament is periodised by these two prophetic personalities (Dt 18: 14-19; 34:10-12, and $1 \mathrm{Ki} \mathrm{17-2} \mathrm{Ki} \mathrm{2.).}{ }^{28}$ Moses as prophet pre-eminent was involved in the birth of Israel as a nation under God. He announced the coming of a prophet 'like me from among you' (Dt 18:18) through whom the Lord would speak to his people (Chapman 2000:118-123). Elijah fitted this description to perfection. Like Moses, God spoke with him face to face; like Moses, he was taken up by God in heaven; like Moses, he was a fearless spokesman of God at a crucial moment in Israel's history. During his ministry 'all Israel' was being reconfigured into a remnant-nation, the 7000 who did not bow the knee to Baal (1 Ki 19:18). From then on it became more and more this remnant of Godfearers, representing 'all Israel' (Ml 3:22), who would experience God's favour, and less and less the nation as a whole. Even though Elijah is not introduced as a Moses redivivus, as no other prophet in the Old Testament he was a prophet like Moses. It is understandable that the editors of Malachi have seen in the forerunner from Malachi 3:1a the prophet Elijah as his final manifestation. At the end not only of this book, but at the end of the Old Testament as a whole, it makes sense that just those two prophetic personalities, with an unparalleled reputation in the postexilic community, are called up from the pre-exilic past to guide them into the future.

\section{Malachi's eschatology assessed}

Malachi's eschatology is now analysed within its own context as outlined in the previous sections. The contention of this article is that eschatology is one of the themes that connects the four prophetic texts studied, and that a theological development has taken place since Haggai started his prophetic ministry ${ }^{29}-$ a development which grew out of the circumstances at the time.

One has to realise that in Malachi too, eschatology is anchored in the past of redemptive history, as attested to in Malachi 1:2-5; 1:6; 2:10; 3:17 and Exodus 19:5 (Snyman 2014:599-600). It shapes the present, which compels the community to live as a Torah-compliant community, conforming to the exhortation in Malachi 3:22 to remember the law of God's servant Moses (Boloje \& Groenewald 2015:4-5).

28.See Kwakkel (2003:11-27); Rupke (2003:29-45); and Snyman (1988:68) for the following argument.

29.See Boda (2007:128-131) for such a development based upon his study of the term mal'akh Yahweh in Haggai, Zechariah and Malachi.

\section{The eschatological future delayed}

The promise of eschatological hope for a future new world order, centred on the temple in Jerusalem ( $\mathrm{Hg} 2: 6-9,20-22)$, is consistently confirmed by Zechariah, 3 Isaiah and Malachi, sometimes even with similar images (Is 62:1-12; 65:17-25; 66:14-22; Hg 2:6-9; Zch 8:1-8, 20-23; 14:8-21; Ml 1:5, 11, 14). Even so, a shift can be noticed: in Malachi the attention is only focused on the eschatological future of the faithful minority in the community, representing 'all Israel'. The nations do not play any significant role in Malachi, unless one follows the contested eschatological interpretation of Malachi 1:5, 11, 14. Otherwise the nations do not appear at the horizon of Malachi's world. ${ }^{30}$ This is in sharp contrast with Haggai, Zechariah and 3 Isaiah, where the nations will share in God's eschatological future, worshipping together with his people in Jerusalem (Is 66:18-21; Zch 14:16-19). This difference is not an indication of Malachi's exclusivist spirituality, focusing only on his own community as an ethnic entity, the onset of early Judaism, which got a firm boost in the times of Ezra and later of Nehemiah (McConville 1986:205-207; Wielenga 2013:1-9). In the present situation of spiritual decline and social disintegration of the community, with the damage done to the temple worship at its heart, God's people could not attract the nations to Jerusalem. The spiritual damage done to the community as God's people had first to be repaired, before she could play again the role God had assigned to her in his eschatological future. It was just this spiritual context which caused a serious delay in the fulfilment of the divine promise of eschatological hope for the future. As already indicated a theological misconception of the covenant must be seen here as explanation. Covenantal promises are not futurological predictions.

In this crisis of eschatological hope delayed, the theme of the Day of the Lord with its warfare imagery has been taken up by Malachi from Zechariah and 3 Isaiah (Is 59:15b-20; 63:1-6; Zch 14:3-15). This signals that the promise of hope will be fulfilled through judgement over the nations but not less over God's people. The announcement of judgement has, firstly, a salvific goal, but if in response a spiritual revival fails to materialise, it can, secondly, turn into its opposite. The remnant minority, standing for 'all Israel', will share in the promised future (Ml 3:16-17; cf Is 61:8; 63:7-64:12; Zch 13:8-9); purified they will come through the refiner's fire. For the wicked judgement will be like a burning furnace; no future to hope for will be left for them (Ml 3:19, 21).

That the intention of this message of judgement was a positive one (a wakeup call to repent and be on their guard) becomes clear from the announcement that God has already sent his messenger to prepare his coming in judgement (Ml 3:1-2), inaugurating, by doing so, a time of grace. As has already been argued, this messenger can be seen as a reference to the prophetic ministry at work among God's people. He has to be clearly distinguished from the messenger of the covenant in Malachi 3:1c; in Malachi 3:23-24 he is rather associated with the prophet Elijah.

30.See Snyman (2014:600) for God's treatment of Edom as a sign of his love for Israe (MI 2:2-5). One does not find here a message for Edom specifically. 


\section{End-time figures}

Like Zechariah and (2 and) 3 Isaiah, Malachi too introduces an enigmatic, unidentified end-time figure (like the Branch and the Servant of the Lord) in the messenger of the covenant. All three of them are involved, each in his own way in the realisation of the eschatological future God will inaugurate. The introduction of this Messenger of the Covenant ${ }^{31}$ is a unique contribution Malachi makes to the Old Testament eschatology. Associated with this Messenger of the Covenant, but clearly distinct from him as well, is the prophet Elijah who is editorially connected with the messenger in Malachi 3:1a. Apart from Moses connecting the present to the past of redemptive history, Elijah is introduced to be waited for before the Day of the Lord will come, thus linking the present with the future of redemptive history.

A last remark concerns the role the Davidic dynasty plays in the eschatological future. Malachi, just like Haggai (Wielenga 2015:8), does not refer to a resurgence of the Davidic house in his own time or in the future. The Branch in Zechariah 6:12-13 will be involved in temple building, and will reign as a royal priest on his throne (Rose 2013:216-218). The Messenger of the Covenant (Ml 3:1c) will restore the covenant with Levi with as result a purified temple worship (Ml 3:2-4). The Servant of the Lord is not linked with monarchical expectations in the short or long term (Wielenga 1998:109-110). In the postexilic literature, the emphasis is on God, the Lord Almighty himself as King over the whole earth (Zch 6:5; 14:9; Ml 1:14). ${ }^{32}$

\section{Conclusion}

In this article an attempt was made to describe the development of the eschatological teachings of the early postexilic prophetic voices from Haggai via Zechariah and 3 Isaiah to Malachi. One can indeed speak of a development grown out of the concrete historical situation in which the early postexilic community found itself. The perceived delay in the advent of the eschatological future is prophetically interpreted as caused by the people's covenantal disobedience, which prevented the eschatological pilgrimage of the nations to Zion from taking place. The promise of the eschatological future is, however, not cancelled but confirmed, although only those who repent of their sins and return to the God of their fathers will, purified and cleansed, inherit the future. The role of the prophetic ministry in the inserted time of grace is crucial here. The development from all Israel to Israel as a remnant is clearly visible in the eschatological discourse in this era. The inauguration of the eschatological future is seen as God's own work, in which he would be assisted by, in Malachi's case, the Messenger of the Covenant. ${ }^{33}$

31.Now we use capital letters to indicate the messianic status this Messenger could have, like the Branch and the Servant of the Lord. The last two messianic figures have been referred to in capital letters throughout this article.

32.See Rose (2013:220-221) for the interpretation of Zechariah 12:7-8, 12-14 (about David). In the book of Chronicles in the late Persian era, the messianic interpretation of 2 Samuel 7 is taken up in connection with the centrality of the temple at Zion (Dirksen 2003:25-26, 33-34): David is portrayed as the temple builder.

33.It is not improbable to identify this Messenger of the Covenant with Jesus Christ in the New Testament (Proctor 1993:9-14).

\section{Acknowledgements Competing interests}

The author declares that he has no financial or personal relationships which may have inappropriately influenced him in writing this article.

\section{References}

Assis, E., 2010, Structure and meaning in the book of Malachi, in J. Day (ed.), Prophecy and prophets in ancient Israel, pp. 354-369, Clark International, Edinburg. (The Library of the Hebrew Bible / Old Testament Series, 531.

Assis, E., 2011, 'Moses, Elijah and the messianic hope: A new reading of Malachi 3:22-24', Zeitschrift für alttestamentliche Wissenschaft 123, 207-220.

Assis, E., 2012a, 'Mutual recriminations: God and Israel in the book of Malachi', Scandinavian Journal of the Old Testament: An International Journal of Nordic Theology 26(2), 207-219.

Assis, E., 2012b, 'The structure of Zechariah 8 and its meaning', Journal of Hebrew Scriptures 12(12), 1-18.

Baldwin, J., 1972, Haggai, Zechariah and Malachi, InterVarsity, Leicester. (Tyndale Old Testament Commentaries).

Bauckham, R., 2008, The Jewish world around the New Testament, Mohr Siebeck, Tübingen.

Bautch, R.J., 2009, 'An appraisal of Abraham's role in postexilic covenants', Catholic Biblical Quarterly 91, 42-63.

Berquist, J.L., 1995, Judaism in Persia's shadow: A social and historical approach, Fortress, Minneapolis.

Beuken, W.A.M., 1979, Jesaja, IIA, Callenbach, Nijkerk. (Prediking van het Oude Testament).

Beuken, W.A.M., 1986, Abraham weet van ons niet (Jesaja 63:16): De grond van Israëls vertrouwen tijdens de ballingschap, Callenbach, Nijkerk. (Inaugural Oration Radboud University Nijmegen).

Beuken, W.A.M., 1990, 'The main theme of Trito-Isaiah: The servants of Yahweh', Journal for the Study of the Old Testament 47, 67-87.

Blenkinsopp, J., 2003, Isaiah 56-66, Doubleday, New York. (Anchor Bible Commentary 19B).

Block, D.I., 2012. Deuteronomy: The NIV application commentary, Zondervan, Grand Rapids.

Blomberg, C.L., 1987, 'Elijah, election, and the use of Malachi in the New Testament', Criswell Theological Review 2(1), 99-117.

Boda, M.J., 2003, 'From fasts to feasts: The literary function of Zechariah 7-8,' Catholic Biblical Quarterly 65, 390-406.

Boda, M.J., 2007, 'Messengers of hope in Haggai - Malachi', Journal for the Study of the Old Testament 32(1), 113-131.

Boda, M.J., 2015, 'Return to me': A biblical theology of repentance, InterVarsity, Downers Grove. (New studies in biblical theology 35).

Boloje, B.O. \& Groenewald, A., 2014, 'Malachi's eschatological Day of Yahweh: Its dual roles of cultic restoration and enactment of social justice (Mal 3:1-5; 3:16-4:6)', Old Testament Essays 27(1), 53-81.

Boloje, B.O. \& Groenewald, A., 2015, 'Malachi's concept of a Torah-compliant community (MI 3:22 [MT]) and its associated implications', HTS Teologiese Studies/Theological Studies 71(3), art. 2990, 1-9.

Bonfiglio, R.P., 2012, 'Archer imagery in Zechariah 9:11-17 in light of Achaemenid iconography', Journal of Biblical Literature 131(3), 507-527.

Chapman, S.B., 2000, The law and the prophets: A study in Old Testament canon formation, Mohr Siebeck, Tübingen. (Forschungen zum Alten Testament 27).

Chapman, S.B., 2003, 'A canonical approach to Old Testament theology? Deuteronomy 34:1-12 and Malachi 3:22-24 as pragmatic conclusions', Horizons of biblical Theology 25(1), 121-145.

Collins, J.J., 1987, The apocalyptic imagination: An introduction to the Jewish matrix of Christianity, Cross Roads, New York.

Collins, J.J., 2003, 'The eschatology of Zechariah', in L.L. Grabbe \& R.D. Haak (eds.), Knowing the end from the beginning: The prophetic, the apocalyptic and their relationships, pp. 74-84, Clark International, London. (Journal for the study of Pseudepigrapha 46)

Cook, S.L., 1995, Prophecy and apocalypticism: The postexilic social setting, Fortress, Minneapolis.

Cook, S.L., 2003, The apocalyptic literature, Abbingdon Press, Nashville. (Interpreting biblical texts).

De Jong, H., 2002, Van oud naar nieuw: De ontwikkelingsgang van het Oude naar het Nieuwe Testament. Kok, Kampen.

Dekker, J., 2015, 'The high and lofty One dwelling in the high and with his servants', Paper delivered at European Association of Biblical Studies conference in Cordoba, 13 July 2015.

Dirksen, P.B., 2003, 1 Kronieken, Kok, Kampen. (Commentaar op het Oude Testament). 
Floyd, M.H., 1999, 'Zechariah and changing views of Second Temple Judaism in recent commentaries', Religious Studies Review 25, 257-263.

Floyd, M.H., 2002, 'The (maśśā') as a type of prophetic book', Journal of Biblical Literature 121(3), 401-422.

Glazier-McDonald, B., 1987a, 'Intermarriage, divorce and the bat- 'el nēkār: insights into Mal 2:10-16', Journal for Biblical Literature 106(4), 6-3-611.

Glazier-McDonald, B., 1987b, Malachi: The divine messenger, Scholars Press, Atlanta. (Society of biblical literature 98 ).

Goswell, G., 2010, 'The fate and future of Zerubbabel in the prophecy of Haggai', Biblica 91, 77-90.

Goswell, G., 2013, 'The eschatology of Malachi after Zechariah 14', Journal for Biblical Literature 132(3), 625-638.

Grabbe, L.L. \& Haak, R.D. (eds.), 2003, Knowing the end from the beginning: The prophetic, the apocalyptic and their relationship, Clark International, London.

Hill, A.E., 1998, Malachi, Doubleday, New York. (Anchor Bible Commentaries 25D).

Kashow, R.C., 2013, 'Zechariah 1-8 as a theological explanation for the failure of prophecy in Haggai 2:20-23', Journal of Theological Studies 64(2), 385-403.

Keown, G.L., 1987, 'Messianism in the book of Malachi', Review and Expositor 84(3), 443-451.

Koole, J.L., 1985, Jesaja II, DI. 1: Jesaja 40-48), Kok, Kampen. (Commentaar op het Oude Testament).

Koole, J.L., 1995, Jesaja III, Kampen, Kok. (Commentaar op het Oude Testament).

Kottsieper, L., 2007, “'And they did not care to speak Yehudit": On linguistic change in Judah during the late Persian era', in O. Lipschitz \& J. Blenkinsopp (eds.), Judah and the Judaeans in the Neo Babylonian period, pp. 95-124, Eisenbraun, Winona Lake.

Kraus, H.-J., 1966, 'Die ausgebliebene Endtheophanie: Eine Studium zu Jes 56-66', Zeitschrift für die alttestamentliche Wissenschaft 78, 317-332.

Kruger, P.A., 2011, 'Reconciliation between fathers and sons in Mal 3:24: A broader Ancient Near Eastern perspective', Old Testament Essays 24(3), 628-651.

Kwakkel, G., 2003, 'lemand als Mozes: Deuteronomium 18:9-22 en de identiteit van de profeet', in G. Kwakkel, Wonderlijk gewoon: Profeten en profetie in het Oude Testament, pp. 11-28, De Vuurbaak, Barneveld. (TU Bezinningsreeks 3).

Landy, F., 2011, 'Three sides of a coin: In conversation with Ben Zwi and Nogalski, two sides of a coin', Journal of Hebrew Scriptures 10, art. 11

Lessing, R.R., 'Amos' earthquake in the book of the Twelve', Concordia Theological Quarterly 74, 243-259.

Lipschitz, O., 2003, 'Demographic changes in Judah between the seventh and fifth centuries bce', in O. Lipschitz \& J. Blenkinsopp (eds.), Judah and the Judaeans in the Neo-Babylonian period, pp. 323-376, Eisenbrauns, Winona Lake.

Malchow, B.V., 1984, 'The messenger of the covenant in Malachi 3:1', Journal of Biblical Literature 103(2), 252-255.

Malone, A.S., 2006, 'Is the Messiah announced in Malachi 3:1?', Tyndale Bulletin 57(2), 215-228.

McConville, J.G., 1984, Law and theology in Deuteronomy, JSOT Press, Sheffield. (Journal of the Study of the Old Testament Supplement Series).

McConville, J.G., 1986, 'Ezra-Nehemiah and the fulfilment of prophecy: Reconsidering Israel and Judah', Vetus Testamentum 36, Fasc 2, 205-224.

McKenzie, S.L. \& Wallace, H.N., 1983, 'Covenant themes in Malachi', Catholic Biblical Quarterly 45, 549-563.

Mitchell, C., 2014, 'A note on the creation formula in Zechariah 12:1-8; Isaiah 42:5-6, and Old Persian inscriptions', Journal of Biblical Literature 133(2), 305-308.

Miller, D., 2007, 'The messenger, the Lord, and the coming judgment in the reception history of Malachi 3', New Testament Studies 53(1), 1-16.

Miller, P.D., 1990, Deuteronomy, John Knox Press, Louisville. (Interpretation).

Mudde, J.M., 1990, De plaats van Jesaja 63:1-6 binnen Jesaja 56-66, Theologische Universiteit, Apeldoorn.

O’Brien, J.M., 1990, Priest and levite in Malachi, Scholars Press, Atlanta. (SBL Dissertations Series 121).

O'Brien, J.M., 1996, 'Judah as wife and husband: Deconstructing gender in Malachi', Journal of Biblical Literature 115(2), 241-250.

Öhler, M., 1997, Elia im Neuen Testament: Untersuchungen zur Bedeutung des alttestamentlichen Propheten in Frühen Christentum, Walter de Gruyter, Tübingen (Beihefte zur Zeitschrift für die neutestamentliche Wissenschaft 88).

Peels, H.G.L., 1992, De wraak van God: De betekenis van de wortel nqm en de functie van de nqm-teksten in het kader van de Oudtestamentische Gods-openbaring Boekencentrum, Zoetermeer.

Petersen, D.L., 1995, Zechariah 9-14 and Malachi: A commentary, Westminster John Knox Press, Louisville. (Old Testament Library).

Pierce, R.W., 1984, 'A thematic development of the Haggai/Zechariah/Malach Corpus', Journal of the Evangelical Theological Society 27(4), 401-411.

Proctor, J., 1993, 'Fire in God's house: Influence of Malachi 3 in the New Testament', Journal of Evangelical Theological Studies 36(1), 9-14.

Rendtorff, R., 2011, The canonical Hebrew Bible: A theology of the Old Testament, 2nd edn., Deo Publishing, Blandford. (Tools for biblical studies series, 7).
Rose, W.H., 2000, Zemah and Zerubbabel: Messianic expectations in the early postexilic period, Sheffield Academic Press, Sheffield. (Journal for the study of the postexilic period, Sheffield Academic Press
Old Testament Supplement Series 304).

Rose, W.H., 2012, 'Zechariah: Prophet of the king of Jerusalem and all the earth', in H.G.L. Peels \& S.D. Snyman (eds.), The lion has roared: Theological themes in the prophetic literature of the Old Testament, pp. 183-196, Pickwick Publications, Eugene.

Rose, W.H., 2013, 'Toekomst voor de koning: Het koningschap in het boek Zacharia', in K. van Bekkum, P.H.R. van Houwelingen \& H.G.L. Peels (eds.), Nieuwe en oude dingen: Schatgraven in de Schrift, pp. 213-230, Vuurbaak, Barneveld. (Apeldoornse Studies 62; TU Bezinningsreek 13).

Rupke, E., 2003, 'Elia, ijveraar voor Jahwe', in G. Kwakkel (ed.), Wonderlijk gewoon: Profeten en profetie in het Oude Testament, pp. 29-46, De Vuurbaak, Barneveld. (TU Bezinningsreek 3).

Seitz, C.R., 2004, 'On letting a text "act like a man": The book of the twelve: New horizons for canonical reading, with hermeneutical reflections', Scottish Bulletin for Evangelical Theology 22, 151-172.

Snyman, S.D., 1988, 'Eschatology in the book of Malachi', Old Testament Essays 1(2), 63-77.

Snyman, S.D., 2004, 'Different meanings a text may acquire: The case of Malachi 1:11', Acta Theologica Supplementum 6, 80-95.

Snyman, S.D., 2006, 'Wie en wat word veroordeel - en waarom? Nogeens Maleagi 2:10-16', In die Skriflig 40(1), 19-33.

Snyman, S.D., 2007, 'Suffering in post-exilic times - Investigating Malachi 3:13-24 and Psalm 1', Old Testament Studies 20(3), 786-797.

Snyman, S.D., 2011, 'Rethinking the demarcation of Malachi 2:17-3:5', Acta Theologica 31(1), 156-168.

Snyman, S.D., 2012, 'Malachi 4:4-6 (Heb 3:22-24) as a point of convergence in the Old Testament or Hebrew Bible: A consideration of the intra and intertextual relationships', HTS Teologiese Studies 68(1), Art. 1195, 1-6.

Snyman, S.D., 2014, 'A theological appraisal of the book of Malachi', Old Testament Essays 27(2), 597-611.

Snyman, S.D., 2015, 'To take a second look at Malachi the book', HTS Teologiese Studies 71(3), Art. 2854, 1-6.

Stromberg, J., 2014, 'Deutero-Isaiah's restoration reconfigured', in L.-S. Tiemeyer \& H.M. Barstad (eds.), Continuity and discontinuity: Chronological and thematic developments in Isaiah 40-66, pp. 195-218, Vandenhoeck \& Ruprecht, Köln. (Forschungen zur Religion und Literatur des Alten und Neuen Testaments 255).

Tiemeyer, L-S., 2005, 'Giving voice to Malachi's interlocutors', Scandinavian Journal of the Old Testament: An International Journal of Nordic Theology 19(2), 173-192.

Tiemeyer, L-S., 2014, 'The doubtful gain of penitential prayer', in T. Bulkely \& M. Bier (eds.), Spiritual complaint: Theology and practice of lament, pp. 102-124, Clarke, Cambridge.

Tollington, J.E., 1993, Tradition and innovation in Haggai and Zechariah 1-8, JSOT Press, Sheffield. (Journal for the Study of the Old Testament Supplement Series 150).

Vandenhooft, D., 2003, 'Babylonian strategies of imperial control in the West: Royal practice and rethoric', in O. Lipschitz, G.N. Knoppers \& R. Albertz (eds.), Judah and the Judaeans in the fourth century bce, pp. 235-262, Eisenbrauns,
Jing Winona Lake.

Van der Woude, A.S., 1982, Haggai, Maleachi, Callenbach, Nijkerk. (Prediking van het Oude Testament).

Van der Woude, A.S., 1984, Zacharia, Callenbach, Nijkerk. (Prediking van het Oude Testament).

Venter, P.M., 2012, 'Trito-Isaiah, penitential prayer and apocalypticism', Verbum et Ecclesia 33(1), 1-12, art. 1718 .

Verhoef, P.A., 1972, Maleachi, Kok, Kampen. (Commentaar op het Oude Testament).

Viberg, A., 1994, 'Wakening a sleeping metaphor: A new interpretation of Malachi 1:11', Tyndale Bulletin 45(2), 297-319.

Westermann, C., 1969, Isaiah 40-66: A commentary, The Westminster Press, Philadelphia (The Old Testament Library).

Weyde, K.W., 2000, Prophecy and teaching: Prophetic authority, form problems, and the use of traditions in the book of Malachi, De Gruyter, Berlin.

Wielenga, B, 1998, Verbond en zending: Een verbondsmatige benadering van zending, Mondiss, Kampen.

Wielenga, B., 2013, 'Renewal and reconstruction: Holy Writ and in Ezra-Nehemiah', In die Skriflig/In Luce Verbi 47(1), 1-9.

Wielenga, B., 2014, 'Covenant and mission: Mission's covenantal character', in B. Wielenga, Bible and mission in Africa: Selected articles, pp. 126-151, Bob Wielenga, Pietermaritzburg.

Wielenga, B., 2015, 'Eschatological hope in Haggai: A homiletic reading', In die Skriflig/ In Luce Verbi 49(1), 1-13, art. 1820.

Wright, C.H.J., 2006, The mission of God: Unlocking the Bible's grand narrative, InterVarsity, Academic, Downers Grove.

Zehnder, M., 2003, 'A fresh look at Malachi 2:13-16', Vetus Testamentum 53(2), 224-259. 